\section{Failing the Part I Clinical}

DeAr SIRS

Having examined four cohorts of trainees over the past two years, and discussed our assessments with other examiners, a reasonable consensus emerges that failure at this important level is most frequently the result of serious errors in one of two basic skills.

Time and time again we have seen trainees fail to make safe and systematic assessments of suicidal risk, and when relevant, homicidal risk. This obviously is a very worrying deficiency and invariably fails the trainee, however satisfactorily the remainder of the clinical is carried out.

To prevent such serious and unnecessary errors we would recommend that clinical tutors allocate structured teaching time to this aspect as part of interview skills training and that trainees not be encouraged to proceed to Part I until they have demonstrated consistently high levels of skill in this area.

The second major cause of failure is in the area of basic descriptive psychopathology. Trainees sometimes do not seem to know the appropriate stem questions for eliciting key psychotic symptoms, get side-tracked or confused when trying to clarify the exact nature of the phenomena they have elicited and then occasionally misclassify what they have elicited.

To remedy this deficiency we would recommend that all training schemes have a key person, usually the clinical tutor, trained in the use of PSE, and subsequently all trainees are given training in the use of the tool prior taking Part I. This would undoubtedly be a major undertaking, probably requiring an initiative from the College, but would do a great deal to ensure a uniformly high level of skill in an essential skill and save a great deal of grief and financial inconvenience for the prospective Part I candidate.

Whiteley Wood Clinic

N. D. MaCaskill Sheffield S10 3TL

Lewisham Mental Health

S. WoOD

Advice Centre, Lewisham SE13

\section{Junior doctors' workloads in psychiatric hospitals}

Dear Sirs

We write in respect of the present on-call load of junior doctors within psychiatric services. This has recently been examined from two most pertinent angles. Firstly, if one may divide this so crudely, the angle of service delivery as outlined by Kingdon \& Szulecka (1986) in their description of a consultant based service in Bassetlaw; secondly, from the viewpoint of the experience obtained by junior psychiatrists in a paper describing a comparison of on-call experiences by Donnelly \& Rice (1989). Locally, consideration of future district plans for the delivery of mental health services is an on-going procedure and in our district, as in many others, focuses in the years ahead on the development of comprehensive provisions of service away from the traditional large mental hospitals. The service envisaged is a mixture of district general hospitals and community based units. Central planning is complex and multifaceted taking in everything from bricks and mortar needs to plan man-power needs. It was in respect of this latter question that attention was drawn to the provision of cover, particularly out of hours, for scattered units and how this may be achieved. This led us to survey the current workload and experience of the on-call doctor at mental hospital base. We present our experience and consider some implications.

The survey itself was conducted over a three month period between 1 March and 31 May 1988, by asking all the junior doctors involved in the on-call rota at Hollymoor Hospital to carry with them a daily $\log$ sheet of their work out of hours and to submit it at 9 o'clock the next morning after their period of on-call work, to us. There was a $95 \%$ return rate of these sheets which consisted of a simple check list to be completed for each out of hours contact. The check list included provision for where the call came from, at what time the call occurred, whether this call necessitated a visit and, in which case, the nature of the visit.

Hollymoor Hospital itself is a 363 bed psychiatric hospital offering a full district service with an average bed occupancy during the three month survey of $90 \%$. The catchment area covered by the hospital consists of a mix of inner city and suburban wards with a total population in the order of 230,000 .

The findings were as indicated in Tables I and II. In considering the implications, the style of the workload can be divided into that requiring some degree of psychiatric training and expertise, such as the assessment of mental state, particularly on admission, work involving the Mental Health Act, or the adjustment of psychotropic medications. Another category of work consists of the assessment and treatment of physical illness or injury and non-Mental Health Act administrative work. This division has important implications for who may provide future on-call service as well as requesting on the questions raised by Donnelly \& Rice on the training nature of existent on-call.

Overall it appeared that the on-call doctors spent approximately $20 \%$ of their time while on-call actually involved in work. Over a period between 5 p.m. on Friday and 9 a.m. on Monday the workload was increased. Although this may be expected, the figures indicated that this increase was very largely made up of expanded work requiring psychiatric expertise within the acute wards of the hospital. It 
TABLE I

\begin{tabular}{lcccc}
\hline & $\begin{array}{c}\text { Psychiatric workload } \\
\text { Acute admission } \\
\text { wards }\end{array}$ & $\begin{array}{c}\text { Psychiatric workload } \\
\text { Geriatric/long stay } \\
\text { wards }\end{array}$ & $\begin{array}{c}\text { General/Admin } \\
\text { Acute admission } \\
\text { wards }\end{array}$ & $\begin{array}{c}\text { General/Admin } \\
\text { Geriatric/long } \\
\text { stay wards }\end{array}$ \\
\hline $\begin{array}{l}\text { Weekdays } \\
\begin{array}{l}\text { Monday-Thursday } \\
\text { Range }\end{array}\end{array}$ & $\begin{array}{c}96 \text { minutes } \\
(0-240 \text { minutes })\end{array}$ & $\begin{array}{c}12 \text { minutes } \\
(0-140 \text { minutes })\end{array}$ & $\begin{array}{c}34 \text { minutes } \\
(0-55 \text { minutes })\end{array}$ & $\begin{array}{c}46 \text { minutes } \\
(0-120 \text { minutes })\end{array}$ \\
\hline $\begin{array}{l}\text { Weekdays } \\
\text { Friday-Monday }\end{array}$ & $\begin{array}{l}145 \text { minutes } \\
\text { Range }\end{array}$ & $\begin{array}{l}7 \text { minutes } \\
(0-60 \text { minutes })\end{array}$ & $\begin{array}{c}39 \text { minutes } \\
(10-240 \text { minutes })\end{array}$ & $\begin{array}{c}36 \text { minutes } \\
(0-145 \text { minutes })\end{array}$ \\
\hline
\end{tabular}

Average (mean) workload over 3 month period.

TABLE II

\begin{tabular}{lccccc}
\hline & $\begin{array}{c}\text { Average total } \\
\text { work time }\end{array}$ & $\begin{array}{c}\text { Average number } \\
\text { of visits to } \\
\text { wards (per day) }\end{array}$ & $\begin{array}{c}\text { Average of work } \\
\text { time (post 11 pm) }\end{array}$ & $\begin{array}{c}\text { Average number } \\
\text { of on-call } \\
\text { admissions }\end{array}$ & $\begin{array}{c}\text { Average number } \\
\text { of contacts to end } \\
\text { on-call (per day) }\end{array}$ \\
\hline $\begin{array}{l}\text { Weekdays } \\
\text { Monday-Thursday }\end{array}$ & 188 minutes & 6.6 & $18 \%$ & 1.00 & 0.3 \\
\hline $\begin{array}{l}\text { Weekends } \\
\text { Friday-Monday }\end{array}$ & 227 minutes & 7.45 & $28.5 \%$ & 1.25 & 0.66 \\
\hline
\end{tabular}

was felt that this may have been influenced by two particular factors, firstly the number of emergency admissions and, secondly, the lack of the normal day to day monitoring of mental state by home teams during the weekend period.

It is possible to compare the rate of emergency admission with that reported by Donnelly \& Rice; in our study the rate of emergency admission was, when corrected for the catchment-during week days 1 admission per 100,000 total population per on-call day every 2.3 days, and at weekends, 1 admission per 100,000 total population per on-call day every 1.9 days. This compares with figures of every 7 days in Sheffield and every 7.6 days in Chichester. In terms of the comparison of a consultant only service it could be seen that such an admission rate would present an onerous duty upon the on-call consultant.

The breakdown in our study was as follows: during weekdays $58 \%$ psychiatric to $42 \%$ medical. At weekends the percentages respectively were $67 \%$ and $33 \%$, which would appear to indicate a rather interesting skew towards a necessity of greater psychiatric expertise at weekends.
It is difficult to directly compare experience with Donnelly \& Rice who did not break down their oncalls into week days and weekends, a division which we feel is a most valid one. A further important distinction we feel, is that between calls before 11 p.m. and after 11 p.m. Obviously our initial question in looking at this was partly related to that posed by the possibility of general practice cover which involves differential rates of pay for calls either side of that divide. It appeared from our results that a significant proportion of the work did occur after 11 o'clock at night.

We present our experience as a commentary which we believe has administrative, planning and training implications. We feel that these questions have not been fully addressed as yet, either in the sphere of future planning towards the break down of large psychiatric hospitals into community units and the effect that that would have on the training of junior psychiatrists in garnering sufficient experience in dealing with emergencies This latter must be recognised as a most essential part of training in psychiatry just as in other specialities in medicine which are in danger of 
becoming lost in services where emergency cover is provided solely by general practitioners or consultants in a de-centralised fashion.

N. S BROWN

Lyndon Clinic

Solihull, West Midlands B92 8PW

\section{References}

Donnelly, P. \& Rice, K. (1989) Comparison of 'on-call' experience in two different training schemes in psychiatry' Psychiatric Bulletin of the Royal College of Psychiatrists, 13, 237-239.

KINGDON, D. G. \& SzULECKA, T. A. (1986) Establishing a district psychiatric service without psychiatric trainees. Psychiatric Bulletin of the Royal College of Psychiatrists, 10, 338-341.

\section{Training schemes}

\section{Dear Sirs}

The comparison of 'on-call' experience by $P$. Donnelly \& K. Rice (Psychiatric Bulletin, May 1989, 13, 237-239) makes interesting reading. Trainees and trainers need to take note of the wide variation in experience available to trainees in the United Kingdom. Variation exists as a result of services developing to meet the needs of the indigent population in the catchment area. In the College (1985) document 'Statement on Approval of Training Schemes for General Professional Training for the MRCPsych' it is significant that emphasis is placed on 'the efforts made to include all available types of local experience into a training scheme'. The College (1981) has recognised the need for any guidelines to permit individual training schemes the flexibility to offer a variety of experiences all acceptable for general psychiatric training.

The Nottingham Psychiatric Rotational Training Scheme, I hope, is not alone in offering trainees the opportunity of experience in a peripheral district general hospital based psychiatric unit. I have recently completed six months in general psychiatry in Mansfield about 15 miles from Nottingham. Most trainees spend at least six months in Mansfield. As there are more consultant posts outside teaching hospitals it follows that eventually most trainees will end up in peripheral psychiatric units at the level of consultant. It seems obvious that early experience at the periphery will prove of lasting value to all trainees.

Trainees in Nottingham and Mansfield are designated the consultant's nominated deputy for the Mental Health Act. I agree with Donnelly \& Rice and consider it invaluable to have responsibility of using the Act. It appears a desirable feature for all rotations and possible with perhaps only minor modifications in existing working practices.

It is essential that prospective trainees are aware of the wide variation of experience and training available even on training schemes which fulfil the criteria for approval by the Royal College of Psychiatrists. This is an issue of concern to the Collegiate Trainees' Committee of which I am a member. We intend to produce a document which will provide prospective trainees with guidelines to assist them in selecting training schemes suitable to their own needs.

Child and Family Therapy Clinic

Ola Junaid Mansfield NG181QJ

\section{References}

Royal College of Psychiatrists (March 1985) Statement on Approval of Training Schemes for General Professional Training for the MRCPsych.

- (1981) Rotational training schemes in psychiatry and assessment of trainees. Bulletin of the Royal College of Psychiatrists, 5, 73-76.

\section{The plight of the Special Hospitals}

DeAR Sirs

'Special Hospital Bashing' is a popular sport among journalists and TV reporters, as recently witnessed by the Cook Report documentary on Park Lane Hospital, broadcast on 22 May 1989. I recall ITV's documentary on Rampton Hospital 'The Secret Hospital' - in May 1979. On that occasion strong criticism was levelled at Rampton Hospital, as a harsh, abusive, custodial institution, which offered its patients little progressive therapy. On this occasion the Cook Report concentrated solely on a particular danger inherent in treating dangerous psychiatric patients; namely, that following treatment, discharge of patients will occur, mistakes will surely eventually be made, and thus disasters of serious re-offending be occasioned, however rare one hopes such incidents might be. Balanced precariously as they are between the need to protect the public from dangerous psychiatric patients and the expectation that they will attempt to 'cure' the same, it is hardly surprising that the Special Hospitals make such inviting targets for journalists.

It is instructive to compare the plight of the Special Hospitals with that of the prisons. Paraphrased in brief terms, the Annual Report of the work of the prison services states that the primary function of the Prison Service is to keep prisoners in custody, with appropriate security, for the duration of their sentences. The rehabilitation of prisoners, or any equivalent, is not mentioned in the Prison Board's Policy 